San Jose State University

SJSU ScholarWorks

Faculty Publications, Biological Sciences

Biological Sciences

December 2014

\title{
Thermal Stress and Predation Risk Trigger Distinct Transcriptomic Responses in the Intertidal Snail Nucella lapillus
}

\author{
Nathaniel D. Chu \\ Northeastern University \\ Luke P. Miller \\ Northeastern University, luke.miller@sjsu.edu \\ Stefan T. Kaluziak \\ Northeastern University \\ Geoffrey C. Trussell \\ Northeastern University \\ Steven V. Vollmer \\ Northeastern University
}

Follow this and additional works at: https://scholarworks.sjsu.edu/biol_pub

Part of the Biology Commons

\section{Recommended Citation}

Nathaniel D. Chu, Luke P. Miller, Stefan T. Kaluziak, Geoffrey C. Trussell, and Steven V. Vollmer. "Thermal Stress and Predation Risk Trigger Distinct Transcriptomic Responses in the Intertidal Snail Nucella lapillus" Molecular Ecology (2014): 6104-6113.

This Article is brought to you for free and open access by the Biological Sciences at SJSU ScholarWorks. It has been accepted for inclusion in Faculty Publications, Biological Sciences by an authorized administrator of SJSU ScholarWorks. For more information, please contact scholarworks@sjsu.edu. 
2 Thermal stress and predation risk trigger distinct transcriptomic responses in the intertidal snail Nucella lapillus

4

5

6 Nathaniel D. Chu ${ }^{1,3^{*}}$, Luke P. Miller ${ }^{1,2}$, Stefan T. Kaluziak ${ }^{1}$, Geoffrey C. Trussell ${ }^{1}$, and Steven 7 V. Vollmer ${ }^{1}$

8

9 1: Northeastern University, Marine Science Center, 430 Nahant Road, Nahant, MA 01908, USA

10 2: Stanford University, Hopkins Marine Station, Pacific Grove, CA 93950, USA

11 3: Current address: Microbiology Graduate Program, Massachusetts Institute of Technology,

12 Cambridge, Massachusetts 02139, USA

13

14 Keywords: thermal stress, nonconsumptive effects, Nucella lapillus, predation risk, RNA-seq,

15 transcriptomics

16

17 * Corresponding author: Nathaniel D. Chu

18 Address: Microbiology Graduate Program, Building 68-139, Massachusetts Institute of

19 Technology, 77 Massachusetts Avenue, Cambridge, MA 02139 USA

20 E-mail: ndchu@mit.edu

21

22 Running headline: Transcriptomic responses to intertidal stress 
24 Thermal stress and predation risk have profound effects on rocky shore organisms, triggering 25 changes in their feeding behavior, morphology, and metabolism. Studies of thermal stress have 26 shown that underpinning such changes in several intertidal species are specific shifts in gene and 27 protein expression (e.g., upregulation of heat-shock proteins). But relatively few studies have 28 examined genetic responses to predation risk. Here, we use next-generation RNA sequencing 29 (RNA-seq) to examine the transcriptomic (mRNA) response of the snail Nucella lapillus to 30 thermal stress and predation risk. We found that, like other intertidal species, $N$. lapillus displays 31 a pronounced genetic response to thermal stress by upregulating many heat-shock proteins and 32 other molecular chaperones. In contrast, the presence of a crab predator (Carcinus maenas)

33 triggered few significant changes in gene expression in our experiment, and this response showed 34 no significant overlap with the snail's response to thermal stress. These different gene expression 35 profiles suggest that thermal stress and predation risk could pose distinct and potentially additive 36 challenges for $N$. lapillus and that genetic responses to biotic stresses such as predation risk might 37 be more complex and less uniform across species than genetic responses to abiotic stresses such 38 as thermal stress. 
40 Rocky shore organisms must regularly cope with intense abiotic and biotic stresses. Chief among

41 these is thermal stress, which often determines intertidal organisms' biogeographic ranges and

42 clinal zonation (Somero 2002; Helmuth et al. 2006). Thermal stress can also alter foraging

43 behavior (Jones and Boulding 1999; Pincebourde et al. 2008), select for heat-resistant phenotypes

44 (Etter 1988; Dong et al. 2008), and induce physiological and cellular changes (Lockwood et al.

45 2010; Connor and Gracey 2011). Cellular responses (e.g., changes in protein and gene

46 expression) to thermal stress have been studied in a variety of intertidal organisms, including

47 algae (Collén et al. 2007; Pearson et al. 2010; Liu et al. 2013), mussels (Gracey et al. 2008;

48 Lockwood et al. 2010; Connor and Gracey 2011; Place et al. 2012), and oysters (Lang et al.

49 2009). A common pattern in these studies was upregulation of genes encoding heat-shock

50 proteins, which act as molecular chaperones during cellular stress (Feder and Hofmann 1999), as

51 well as upregulation of genes encoding apoptosis regulators and other protein chaperones.

Recently, a growing body of work has demonstrated that predation risk can also be a

53 major source of stress for rocky shore organisms (Long and Hay 2012; Benedetti-Cecchi and

54 Trussell 2014). In addition to exerting well-known consumptive effects on their prey-whereby a

55 predator alters prey population density by actively consuming individuals (Paine 1966) -

56 predators also exert nonconsumptive effects, where the risk of predation alone alters prey

57 behavior and morphology (Trussell et al. 2006a). Rocky shore organisms often detect predation

58 risk via waterborne cues (Trussell et al. 2003) and respond by reducing foraging activity, which

59 can produce cascading indirect effects throughout the community. The strength of these effects

60 can rival or exceed those caused by predators actively consuming prey (Trussell et al. 2006a).

61 Moreover, as with thermal stress, emerging evidence indicates that stress imposed by predation 
62 risk can trigger elevated respiration (Rovero et al. 1999) and increased production of heat-shock

63 proteins (Pijanowska and Kloc 2004; Pauwels et al. 2005; Slos and Stoks 2008), antioxidant

64 enzymes (Slos and Stoks 2008), and stress hormones (Creel et al. 2009; Sheriff et al. 2009).

65 These physiological shifts likely exert additional energetic costs on prey species and may explain

66 why some prey grow less efficiently under predation risk (Trussell et al. 2006b, 2008).

67 To date, only a few studies have examined the genetic responses of organisms to

68 predation risk. These studies were done on planktonic crustaceans (Pauwels et al. 2005;

69 Schwarzenberger et al. 2009; Miyakawa et al. 2010; Spanier et al. 2010), tadpoles (Mori et al.

70 2009), guppies (Fraser et al. 2011), three-spined sticklebacks (Sanogo et al. 2011), and goldfish

71 (Kagawa and Mugiya 2002). Many earlier studies examining molecular responses to predation

72 risk used methods similar to those used to study abiotic stresses such as thermal and oxidative

73 stress, often focusing on expression of heat-shock proteins or antioxidant enzymes (Kagawa and

74 Mugiya 2002; Pijanowska and Kloc 2004; Pauwels et al. 2005; Slos and Stoks 2008). But later

75 studies, employing high-throughput tools such as microarrays or transcriptomics, have shown few

76 similarities in how species change gene expression in response to predation risk, which contrasts

77 with well-established gene expression patterns during thermal stress (Mori et al. 2009; Fraser et

78 al. 2011). Consequently, it is difficult to conclude from research to date whether predation stress

79 triggers similar transcriptomic responses across many species — as heat stress does — or whether

80 each species mounts a unique type of genetic response to its predators.

81 Here, we examine the genetic responses of the intertidal snail Nucella lapillus to both

82 thermal stress and predation risk. Nucella lapillus sits in the middle of a three-level food chain,

83 between its predator (the crab Carcinus maenas) and prey (the mussel Mytilus edulis and the

84 barnacle Semibalanus balanoides). In this system, waterborne cues from $C$. maenas induce 
85 decreased feeding, lower growth rates, and thicker shells in N. lapillus (Stickle et al. 1985;

86 Palmer 1990; Trussell et al. 2003, 2006b); in turn, reductions in feeding rates can produce strong

87 cascading indirect effects in the resident community (Trussell et al. 2003). Past work has also

88 documented the effects of thermal stress on the snail's color polymorphisms (Etter 1988),

89 population structure (Chu et al. 2014), and protein expression (Gardeström et al. 2007). Using

90 RNA-seq, we sought to further understand the genetic responses to a well-characterized abiotic

91 stress (thermal stress) and a less-understood biotic stress (predation risk) within this well-studied

92 intertidal food chain. In addition, we sought to uncover the potential overlap between these

93 genetic responses to better understand how the interactive effects of thermal stress and predation

94 risk may influence $N$. lapillus. Although thermal stress and predation risk often have similar

95 organismal and ecological effects - e.g., decreased foraging and lower metabolic efficiency - we

96 found that $N$. lapillus's genetic responses to these factors were markedly different. The snail

97 responded to thermal stress in a manner similar to other species, but we found few significant

98 changes in gene expression in response to predation risk. In the context of past research, our

99 findings suggest that genetic responses to biotic stresses, such as predation risk, may be more

100 complex and less uniform across species than genetic responses to abiotic stresses, such as

101 thermal stress.

102

103

\section{METHODS}

104 To examine the genetic responses of $N$. lapillus to thermal stress and predation risk, we exposed 105 snails to three treatments: control conditions (no stress), risk cues from the predatory green crab

106 C. maenas (predation risk), and elevated temperature (thermal stress). In June 2010, we collected

107 snails from Nahant, MA, near Northeastern University's Marine Science Center, where we 
108 performed our experiments. First, snails were acclimated for almost two months in aquaria with 109 an ambient supply of seawater from the Marine Science Center's flow-through system and a 110 steady supply of mussel prey (M. edulis). During the acclimation period, the snails were not 111 directly exposed to crab risk cues beyond any trace cues that may have come in from the sea 112 water system. Second, snails were placed in experimental mesocosms for a total of 17 days 113 (during August and September 2010). Third, all experimental snails were flash-frozen in liquid 114 nitrogen for genetic processing.

115 Each mesocosm had an independent water supply and a population of 30 mussels as prey, 116 which was replenished every 6 days. Three control-treatment snails were kept at ambient 117 temperature $\left(15.75 \pm 1.1{ }^{\circ} \mathrm{C}\right.$ [mean \pm 1 standard deviation], total range $\left.12.1-20.3{ }^{\circ} \mathrm{C}\right)$ with an 118 ambient supply of seawater from the Marine Science Center's flow-through system. For our 119 predation risk treatment, four snails were kept at ambient temperature, but throughout the 17-day 120 experimental period, their water supply first passed through a chamber containing a green crab 121 (C. maenas) feeding on N. lapillus to simulate predation risk, as in Trussell et al. (2006b). For our 122 thermal stress treatment, two snails were kept in mesocosms at ambient temperature without 123 crabs and with an ambient supply of seawater. These snails were removed from the mesocosms, 124 brought to an internal body temperature of $33^{\circ} \mathrm{C}$ under a heat lamp over a period of 4.5 hours at a 125 rate of $1.8^{\circ} \mathrm{C} \mathrm{min}{ }^{-1}$, and finally placed back in ambient-temperature mesocosms for a 2-hour 126 recovery period before we flash-froze them for RNA-seq. We began RNA-seq library preparation by homogenizing at total of $25 \mathrm{mg}$ of tissue from 128 each snail's head, foot, and mantle tissue in TRI Reagent. We extracted total RNA following the 129 manufacturer's protocol and quantified total RNA using an Agilent Bioanalyzer and an RNA 1306000 Pico Chip (see Figure S1). We used only samples that had an RNA integrity number (RIN) 
131 higher than 7. We then extracted mRNA by poly A+ selection using Dynabeads Oligo(dT) from

132 Life Technologies. We prepared unstranded Illumina mRNA-seq libraries as in Craig et al.

133 (2008), with the following modifications: we used fragmentase (NEB) to fragment the cDNA

134 libraries, we size-selected for cDNA fragments $~ 250$ base pairs in length, and we used custom 4-

135 base-pair barcodes for each individual. We also used random primers during first-strand synthesis

136 to avoid 3' bias from Oligo(dT) primers. We quantified our final libraries using a Bioanalyzer

137 DNA 1000 chip and sequenced them on an Illumina GAIIx using single-end, 50-base-pair reads.

138 To identify differentially expressed genes from our Illumina sequence data, we first used

139 custom Perl scripts to filter sequence output to remove sequence reads having a Phred Quality

140 score less than 30, more than one ambiguous nucleotide, or Illumina adapter sequences. We also

141 filtered these sequence reads for rRNA contamination using the National Center for

142 Biotechnology Information's (NCBI) metazoan dataset and Bowtie v 0.12.7 (Langmead et al.

143 2009), applying default parameters. To assemble our RNA sequences into contigs — each

144 representing a putative mRNA transcript — we used Trinity with default parameters, except that

145 we set the path-reinforcement distance to 85 to account for potential polyploidy (Grabherr et al.

146 2011). We annotated the assembled transcriptome with Blastx v 2.2.27+ against the UniProtKB

147 Swiss-Prot database, using the BLOSUM50 substitution matrix and an e-value cutoff of $10^{-5}$. We

148 used the relatively permissive BLOSUM50 matrix because of the scarcity of genetic data for

149 molluscs. We used Bowtie v 0.12.7 to map RNA-seq reads from each individual snail to the

150 annotated transcriptome and used Express to quantify for each snail the number of reads mapping

151 to each individual assembled transcript (Langmead et al. 2009; Roberts and Pachter 2013). The

152 software package eXpress did not detect any significant 3' bias because of poly A+ selection

153 (Dryad, express files). We analyzed differential expression using the DESeq2 package in $\mathrm{R} \mathrm{v}$ 
154 3.0.2, using the default adjusted $P$-value cutoff of 0.1 (Anders and Huber 2010). We also tested $155 P$-value cutoffs of $0.05,0.2$, and 0.3 . At a cutoff of 0.05 , there were no differentially expressed 156 transcripts in the snails exposed to predation risk, and at 0.2 and 0.3 there were no additional 157 differentially expressed transcripts beyond those identified by the default $P$-value cutoff of 0.1 .

158 Default independent filtering during DESeq2 analysis filtered out transcripts unlikely to be 159 differentially expressed using the mean of normalized counts as a filer statistic (Anders and 160 Huber 2010). We plotted biological processes associated with differentially expressed genes 161 according to their functional similarity using $\operatorname{Sim}_{\text {Rel }}$ (Schlicker et al. 2006) and REVIGO (Supek 162 et al. 2011), setting the allowed similarity to 0.7 and querying the UniProt database.

163

164

165

166

167

168

169

170

171

172

173

174

175 temperature, 135 of them were upregulated and 6 were downregulated. The upregulated genes

176 included six heat-shock proteins; an additional protein chaperone (BAG family regulator 5, which 
177 activates heat-shock protein 70); as well as genes mediating immune defenses (myeloperoxidase),

178 inflammation (acyloxyacyl hydrolase), apoptosis (baculovial IAP repeat-containing protein 2,

179 BAG family regulator 5, myeloperoxidase, hemocyte protein-glutamine gamma-

180 glutamyltransferase), oxidation stress (peroxidase), and metabolism (acyloxyacyl hydrolase,

181 acidic phospholipase A2 PA4) (Table 1, Figure 2). The most strongly upregulated genes were for

182 heat-shock $70 \mathrm{kDa}$ protein cognate 1 and DNAJ homolog subfamily B member 4 (also known as

183 heat-shock protein 40), both of which operate as molecular chaperones during stress (Feder and

184 Hofmann 1999; Borges et al. 2005). None of the downregulated transcripts mapped to a protein-

185 coding gene. In sum, the most significantly upregulated genes were associated with stress

186 response, protein folding, metabolism, and inflammatory response (Gene Ontology Consortium,

187 http://www.geneontology.org; Figure 2).

188 In contrast, our DESeq analyses identified only three differentially expressed transcripts

189 in snails exposed to predation risk (Figure 1), and none of these three were differentially

190 expressed in snails exposed to elevated temperature. Of the three differentially expressed

191 transcripts induced by predation risk, one was upregulated and two were downregulated. The

192 upregulated transcript did not annotate to a known gene and, from raw read counts, appears to

193 have been differentially expressed in only one snail (Grubbs' test, $M=17.25, S D=23.23, P<$

194 0.05; Supplementary File 2). The two downregulated transcripts both annotated to saxiphilin, a 195 toxin-binding protein involved in iron transport (Morabito and Moczydlowski 1994; Negri and

196 Llewellyn 1998; Figure 2; Table 1).

197

198

DISCUSSION

199 New, next-generation sequencing technologies are enabling transcriptomic analysis with much 
200 greater depth, detail, and precision than before (Mardis 2008). Compared with a previously

201 published transcriptome used to study N. lapillus's response to tributyltin, a pollutant that acts as

202 an endocrine disrupter (Pascoal et al. 2013), our transcriptome assembly was both larger and

203 more annotated. The previous Roche 454-based transcriptome assembled using Roche 454's

204 Newbler assembly software was approximately one-third the size of our assembly, with a lower

205 annotation rate of approximately $2.5 \%$ (Pascoal et al. 2013), compared with our annotation rate of

$20623.1 \%$. These differences reflect both the increasing throughput of next-generation sequencing

207 platforms and the growing power of short-read assembly algorithms like those used in Trinity

208 (Grabherr et al. 2011).

Our RNA-seq analyses revealed distinct gene expression responses to thermal stress and

210 predation risk among the $N$. lapillus in our experiments. Despite similar potential effects exerted

211 by both these stresses — such as decreased feeding and growth efficiency — the snails evidently

212 compensated for each stress via independent processes. The difference between the genetic

213 responses to thermal stress and predation risk suggests that these stressors could be additive in

214 their impact on N. lapillus, as each stress appeared to trigger separate genetic pathways.

215 We found that $N$. lapillus had a genetic response to thermal stress similar to those of other

216 intertidal organisms (Lang et al. 2009; Place et al. 2012), involving the upregulation of genes

217 associated with multiple heat-shock proteins, apoptosis, and other molecular chaperones. Heat-

218 shock proteins are a well-described set of proteins mediating cellular damage, which are often

219 upregulated in response to elevated temperature and other environmental stresses, such as

220 oxidation, and these proteins occur in all three phylogenetic domains (Feder and Hofmann 1999;

221 Kregel 2002). The magnitude of $N$. lapillus's response, including upregulating heat-shock 70

222 protein by more than 23 times, likely reflects the extreme temperature variation that the species 
223 experiences in the intertidal zone (Somero 2002). We also observed a strong upregulation (by

2248.69 times) of acyloxyacyl hydrolase, which is associated with inflammation responses (Hagen $e t$

225 al. 1991; Cody et al. 1997) and lipid metabolism (Munford and Hunter 1992). These

226 differentially expressed genes show that when exposed to high temperatures, $N$. lapillus mounts a

227 significant response, stabilizing cellular and molecular machinery and potentially altering

228 metabolic pathways to meet additional energetic needs. These results align with thermal-stress

229 experiments in other species, which often show similar shifts in gene expression (Lang et al.

230 2009; Connor and Gracey 2011; Place et al. 2012).

231 In contrast to the response we observed to thermal stress, we found a less pronounced

232 response to predation risk. The single upregulated transcript appears to have been upregulated in

233 only one of the snails exposed to predation risk (Supplementary File 2). The two downregulated

234 transcripts annotated to saxiphilin, a protein that binds saxotoxin, a well-known paralytic shellfish

235 toxin (Negri and Llewellyn 1998). It is unclear what role this protein might play in a response to

236 predation risk. In addition, it appears that six related genes that were downregulated in response

237 to thermal stress appear to be similarly downregulated in response to predation risk (Dryad, read

238 count table: transcripts comp34986_c0_seq[1, 4-8]), although DESeq2 did not identify these

239 genes as statistically significant. These genes are unannotated and merit further investigation

240 because of their potential role in responses to both thermal stress and predation risk.

241 We were surprised that few genes were differentially expressed in response to predation

242 risk, given that such risk has been shown to induce strong changes in the snail's behavior [e.g.,

243 predator avoidance (Matassa and Trussell 2011)], morphology [e.g., shell thickening(Palmer

244 1990)], and metabolism [e.g., reduced growth efficiency (Trussell et al. 2006b)]. It may be that

245 our sampling missed the temporal scale at which predation risk triggers changes in gene 
246 expression: perhaps the snails had not yet responded to predator cues or they had become

247 acclimated or desensitized to them during the experiment. Such a sampling effect would appear

248 unlikely, however, given that (1) the ecological effects of predation risk in $N$. lapillus persist at

249 high levels for weeks or longer (Matassa and Trussell 2011); (2) snails were acclimated in crab-

250 free mesocosms before all experiments, thus minimizing potential preexperimental exposure to

251 predator cues; and we sampled during a peak period of predation risk effects documented in this

252 system (Trussell et al. 2006a, 2006b). Furthermore, other studies have detected significant

253 physiological effects after as little as 12 days of incubation (Matassa and Trussell 2011), and

254 snails that were maintained in parallel with this experiment (from the same collection and

255 acclimation period, used in a different study) showed significant decreased growth efficiency and

256 foraging behavior in responses to crab cues during our 17-day incubation period (Miller et al.

257 2014). It is also possible that $N$. lapillus's genetic response to predation risk is tissue specific, so

258 by pooling tissue types, we might have missed a response.

259 Finally, our depth of sequencing may not have been sufficient to capture a response to predation

260 risk, particularly if changes in gene expression were modest. This possibility could have been

261 exacerbated by DESeq2's analysis pipeline, which filters out genes if the mean of normalized

262 counts is below a given threshold (Anders and Huber 2010). By filtering out such low-expression

263 genes, DESeq2 reduces the probability of false positives and increases statistical power (Bourgon

264 et al. 2010), but it also increase the chance of false negatives for genes expressed at very low

265 levels. Our sequencing depth may also not have been sufficient to cover $N$. lapillus's genome,

266 which is estimated to be approximately 2.6 gigabases (Pascoe et al. 2004). This species' genome

267 has not been sequenced, and mapping to a de novo transcriptome assembly is inherently less

268 efficient than mapping to a sequenced genome. 
Our results suggest that when applying transcriptomics to study complex ecological

270 phenomena, one must keep in mind the limitations of RNA-seq and take into account the

271 experimental design and sequencing depth used. The Encyclopedia of DNA Elements

272 (ENCODE) Consortium's guidelines for RNA-seq studies suggest a minimum of two biological

273 replicates and 30 million paired-end reads per sample in human studies

274 (https://www.encodeproject.org/), although some research has reported diminishing returns after

27510 million reads (Liu et al. 2013). Indeed, quite a few recent studies do not meet ENCODE's read

276 depth standards, in part, because of the sequencing costs. Such variations highlight the

277 importance of experimental context when interpreting RNA-seq results, which are comparative.

278 In our study, the detection of few differentially expressed genes in response to predation risk

279 likely suggests that responding to predation involves more subtle changes in gene expression than

280 responding to thermal stress. More detailed sampling and sequencing may be needed to uncover

281 these processes. As sequencing technology and RNA-seq methodologies continue to mature, the

282 sensitivity of these tools will no doubt grow and costs decrease, which should enable us to find

283 and clarify phenomena we might have missed at first.

284 Even so, if more frequent sampling, tissue separation, or greater sequencing depth were

285 necessary to identify differentially expressed genes in response to predation risk, these factors

286 alone would not likely explain the comparatively less extensive genetic response we found to

287 predation risk than to thermal stress. This notable difference is consistent with the idea that

288 elevated temperature poses a more critical threat to $N$. lapillus than predation and that the extreme

289 daily and seasonal thermal fluctuations of the intertidal zone are the primary drivers of stress on

290 rocky shores (Helmuth and Hofmann 2001; Somero 2002). Even though the ecological impacts of

291 moderate thermal stress and predation risk can be similar in magnitude (Miller et al. 2014), the 
292 intensity of thermal stress in intertidal habitats may require a more extensive genetic response to

293 survive periods of high temperature. In contrast, the spatial distribution and temporal scales of

294 predator risk vary greatly (Turner and Montgomery 2003) and may require fewer genetic

295 changes.

296 N. lapillus's relatively modest genetic response to predation risk might also involve more

297 moderate changes to gene expression and complex shifts in behavior and physiology than its 298 response to thermal stress. Although mitigating thermal stress requires upregulating molecular 299 chaperones to maintain crucial cellular processes, avoiding predation involves hiding (Matassa 300 and Trussell 2011), increased shell production (Palmer 1990), and changes in metabolism

301 (Trussell et al. 2006b) in N. lapillus, and these plastic responses likely involve a diverse 302 complement of genes. Future work with deeper sequencing, more sampling over multiple time 303 points, and sampling of individual tissue types may improve our ability to detect changes in gene 304 expression associated with behavioral responses to predation risk in N. lapillus and other species. 305 In addition, when considered within the context of previous research on predator-induced 306 gene expression, our data suggest that the genetic response to predation risk might be less 307 uniform across species than the response to thermal stress. Thermal stress is often considered one 308 of the most fundamental stresses an organism can confront, and studies of genetic responses to 309 thermal stress from species from all three phylogenetic domains show a similar pattern of 310 upregulating heat-shock proteins and other chaperone proteins (Feder and Hofmann 1999).

311 Although past studies using single- or multiple-gene techniques found that some prey species 312 upregulate heat-shock proteins in response to predators (Kagawa and Mugiya 2002; Pijanowska 313 and Kloc 2004; Slos and Stoks 2008), more recent studies using microarrays and transcriptomics 314 in other species found that the presence of predators does not always trigger the upregulation of 
315 stress-mediating genes associated with thermal or oxidation stress. These studies found different

316 responses to predation risk for each organism (Mori et al. 2009; Miyakawa et al. 2010; Fraser et

317 al. 2011). Nishimura and colleagues, for example, have studied predator-induced phenotypes in

318 the tadpole of Rana pirica, which can produce a "bulgy" morphology that prevents predation by

319 larval salamanders (Kishida et al. 2007). Using microarrays, the researchers found that bulgy-

320 morph tadpoles differentially expressed a number of genes mediating cell adhesion and structure,

321 including the upregulation of NADH dehydrogenase, aldehyde dehydrogenase, and uromodulin-

322 like genes and downregulation of keratin-related genes (Mori et al. 2009). Their results suggest

323 that changes in tadpole gene expression were specifically linked to the pronounced phenotypic

324 changes preventing predation. Besides our study, only one other has used high-throughput

325 transcriptomic techniques to assess genetic responses to predation risk. This study examined a

326 species of guppy (Poecilia reticulata) and found that two genes encoding cerebellin proteins were

327 the most upregulated in response to cues from a fish predator (Fraser et al. 2011). These studies

328 indicate that not all species upregulate typical stress proteins in response to predation risk, and

329 particular responses for each species may reflect the diversity of behavioral and physiological

330 strategies taken by different organisms to reduce their vulnerability to predation. A better

331 understanding of the genetic underpinnings of complex biotic stresses will require high-

332 throughput transcriptomic approaches to identify specialized responses, because such responses

333 are likely to be missed by lower-throughput analyses.

\section{CONCLUSIONS}

336 Using RNA-seq analyses, we found notably different genetic responses to thermal stress and 337 predation risk in N. lapillus. Thermal stress invoked vigorous upregulation of many stress-related 
338 genes, similar to responses in other intertidal organisms. In contrast, predation risk triggered a

339 much less marked response. These results suggest that thermal stress and predation risk may

340 present fundamentally different challenges to $N$. lapillus. In the context of previous studies, our

341 findings suggest that genetic responses to biotic stresses, such as the risk of predation, may be

342 less uniform than genetic responses to abiotic stresses, such as thermal stress, and that further

343 studies using transcriptomic tools may further uncover unique and subtle genetic responses

344 mounted by different species to avoid predation.

\section{ACKNOWLEDGMENTS}

347 Funding was generously provided by National Science Foundation grants OCE-0727628 to GCT, 348 OCE-0848345 to SVV, and OCE-0963010 to the Marine Science Center as part of the Academic

349 Research Infrastructure Recovery and Reinvestment Program. We thank Ellen W. Chu for

350 comments on the manuscript. For scripts and more information, please visit

351 http://nathanieldavidchu.wordpress.com.

\section{DATA ACCESSIBILITY}

354 -RNA-seq raw sequence reads: NCBI SRA-SRX357400

355 -Transcriptome assembly: Dryad repository-doi: 10.5061/dryad.610dd

356 -Express files will be deposited in the Dryad repository

\section{AUTHOR CONTRIBUTIONS}

359 LPM, GCT, and SVV conceived and designed the research. LPM prepared sequencing libraries. 360 NDC and STK analyzed data. NDC wrote the first draft, and LPM, GCT, and SVV contributed 

significantly to revisions.

\section{TABLES}

364 Table 1. Gene annotations of differentially expressed transcripts in snails exposed to elevated 365 temperature (thermal stress) and predation risk (predation risk). $n$ values in parentheses indicate 366 that multiple differentially expressed transcripts annotated to this gene, and in these cases, we 367 report the range of $P$-values found.

\begin{tabular}{|c|c|c|c|c|}
\hline $\begin{array}{l}\text { Gene transcript } \\
\text { annotation }\end{array}$ & $\begin{array}{l}\text { Uniprot } \\
\text { ID }\end{array}$ & $\begin{array}{l}\log _{2} \\
\text { fold } \\
\text { change }\end{array}$ & $\begin{array}{l}\text { Adjusted } \\
P \text {-value }\end{array}$ & Activity \\
\hline \multicolumn{5}{|c|}{ Thermal stress } \\
\hline $\begin{array}{l}\text { Heat-shock } 70 \mathrm{kDa} \\
\text { protein cognate } 1\end{array}$ & P02826 & 4.53 & $3.82 \mathrm{e}-09$ & $\begin{array}{l}\text { Heat-shock proteins act as } \\
\text { molecular chaperones during } \\
\text { heat and other stresses (Feder } \\
\text { and Hoffmann 1999). }\end{array}$ \\
\hline $\begin{array}{l}\text { Heat-shock } 70 \mathrm{kDa} \\
\text { protein } 16\end{array}$ & Q9SAB1 & 2.73 & 0.005 & \\
\hline $\begin{array}{l}\text { Heat-shock cognate } 70 \\
\text { kDa protein } 1^{*}\end{array}$ & P36415 & 2.59 & 0.008 & \\
\hline Heat-shock protein 83 & O16087 & 2.34 & 0.039 & \\
\hline $\begin{array}{l}78 \mathrm{kDa} \text { glucose-regulated } \\
\text { protein }(n=3)\end{array}$ & P34935 & $\begin{array}{l}2.69- \\
2.70\end{array}$ & 0.005 & $\begin{array}{l}\text { Belongs to the heat-shock } \\
\text { protein } 70 \text { family; involved in }\end{array}$ \\
\hline
\end{tabular}




\begin{tabular}{|c|c|c|c|c|}
\hline & & & & $\begin{array}{l}\text { protein folding in the } \\
\text { endoplasmic reticulum } \\
\text { (Chang et al. 1987). }\end{array}$ \\
\hline $\begin{array}{l}\text { BAG family molecular } \\
\text { chaperone regulator } 5 \\
\text { (nucleotide exchanger for } \\
\text { HSP70) }\end{array}$ & Q5QJC9 & 2.82 & 0.004 & $\begin{array}{l}\text { Acts as a protein chaperone } \\
\text { and activates heat-shock } \\
\text { proteins (Kalia et al. 2004). }\end{array}$ \\
\hline $\begin{array}{l}\text { DnaJ homolog subfamily } \\
\text { B member } 4 \text { (probable } \\
\text { chaperone) }(n=2)\end{array}$ & Q9D832 & $\begin{array}{l}4.40- \\
4.44\end{array}$ & $3.82 \mathrm{e}-09$ & $\begin{array}{l}\text { Acts as a protein chaperone, } \\
\text { and is also known as heat- } \\
\text { shock protein } 40 \text { (Borges et } \\
\text { al. } 2005 \text { ). }\end{array}$ \\
\hline $\begin{array}{l}\text { Baculoviral IAP repeat- } \\
\text { containing protein } 2(n= \\
\text { 2) }\end{array}$ & Q62210 & $\begin{array}{l}2.56- \\
2.61\end{array}$ & $\begin{array}{l}0.015- \\
0.018\end{array}$ & $\begin{array}{l}\text { Mediates cellular apoptosis } \\
\text { (Rothe et al. 1995). }\end{array}$ \\
\hline Myeloperoxidase & P05164 & 2.54 & 0.020 & $\begin{array}{l}\text { Involved in immune defense } \\
\text { (Nauseef et al. 1996), } \\
\text { apoptosis regulation (Wagner } \\
\text { et al. 2000), and inflammation } \\
\text { responses (Hashinka et al. } \\
\text { 1988). }\end{array}$ \\
\hline Acyloxyacyl hydrolase & P28039 & 3.12 & 0.001 & $\begin{array}{l}\text { Involved in inflammation } \\
\text { responses and lipid }\end{array}$ \\
\hline
\end{tabular}




\begin{tabular}{|c|c|c|c|c|}
\hline & & & & $\begin{array}{l}\text { metabolism (Hagen et al. } \\
\text { 1991). }\end{array}$ \\
\hline Peroxidase $(n=2)$ & Q01603 & $\begin{array}{l}2.47- \\
2.49\end{array}$ & $\begin{array}{l}0.027- \\
0.029\end{array}$ & $\begin{array}{l}\text { Breaks down free-radical } \\
\text { products of inefficient cellular } \\
\text { metabolism (Ng et al. } 1992) \text {. }\end{array}$ \\
\hline $\begin{array}{l}\text { Hemocyte protein- } \\
\text { glutamine gamma- } \\
\text { glutamyltransferase } \\
\text { (protein synthesis } \\
\text { catalyst) }\end{array}$ & Q05187 & 2.13 & 0.098 & $\begin{array}{l}\text { Catalyzes peptide cross- } \\
\text { linking and potentially plays a } \\
\text { role in programmed cell death } \\
\text { (Tokunaga et al. } 1993 \text { ). }\end{array}$ \\
\hline Prestin & Q9JKQ2 & 2.27 & 0.085 & $\begin{array}{l}\text { Acts as a motor protein and } \\
\text { helps regulate cell shape } \\
\text { (Zheng et al. 2000). }\end{array}$ \\
\hline $\begin{array}{l}\text { Acidic phospholipase A2 } \\
\text { PA4 }\end{array}$ & P80003 & 2.36 & 0.055 & $\begin{array}{l}\text { Involved in lipid metabolism } \\
\text { and host defense (Dennis et } \\
\text { al. 1991). }\end{array}$ \\
\hline $\begin{array}{l}\text { Patched domain- } \\
\text { containing protein } 3 \\
\text { (sperm development) }\end{array}$ & Q0EEE2 & 2.66 & 0.011 & $\begin{array}{l}\text { Potentially regulates } \\
\text { hedgehog signaling in male } \\
\text { germ cells (Fan et al. 2007). }\end{array}$ \\
\hline
\end{tabular}




\begin{tabular}{|c|c|c|c|c|}
\hline $\begin{array}{l}\text { IgE-binding protein }(n= \\
\text { 2) }\end{array}$ & P03975 & $\begin{array}{l}2.42- \\
2.50\end{array}$ & $\begin{array}{l}0.021- \\
0.032\end{array}$ & $\begin{array}{l}\text { Mediates immunoglobulin } \\
\text { (antibody) responses (Ishizaka } \\
\text { 1984). }\end{array}$ \\
\hline $\begin{array}{l}\text { Retrovirus-related Pol } \\
\text { polyprotein from } \\
\text { transposon } 412(n=3)\end{array}$ & P10394 & $\begin{array}{l}2.30- \\
2.73\end{array}$ & $\begin{array}{l}0.007- \\
0.065\end{array}$ & $\begin{array}{l}\text { Acts as a transposable } \\
\text { element (Yuki et al. 1986). }\end{array}$ \\
\hline $\begin{array}{l}\text { RNA-directed DNA } \\
\text { polymerase from mobile } \\
\text { element jockey }\end{array}$ & P21329 & 2.44 & 0.035 & $\begin{array}{l}\text { Acts as a mobile DNA } \\
\text { element (Mizrokhi and Mazo } \\
\text { 1990). }\end{array}$ \\
\hline \multicolumn{5}{|c|}{ Predation risk } \\
\hline Saxiphilin $(n=2)$ & P31226 & $\begin{array}{l}-2.78- \\
2.74\end{array}$ & 0.093 & $\begin{array}{l}\text { Binds saxotoxin, a toxin } \\
\text { found in shellfish (Negri and } \\
\text { Llewellyn 1998). }\end{array}$ \\
\hline
\end{tabular}

*Heat-shock cognate $70 \mathrm{kDa}$ protein 1 was the second most significant blast hit (e-value $=6 \mathrm{e}-$

15). The most significant Blast hit was a heat-shock 70 protein from chloroplast membranes.

\section{FIGURE LEGENDS}

372 Figure 1. Differential gene expression in (a) snails exposed to elevated temperature versus control 
373 snails and (b) snails exposed to predation risk versus control snails. Each point in these volcano

374 plots represents a gene transcript; red dots are differentially expressed transcripts that had an

375 adjusted $P$-value of $<0.1$.

376

377 Figure 2. Biological processes associated with differentially expressed transcripts, as defined by

378 the Gene Ontology project. Red circles represent genes differentially expressed in snails exposed

379 to elevated temperatures, and blue circles represent those from snails exposed to predation risk.

380 Circle size is proportional to the absolute value of the $\log _{10}$ of the reported DESeq2 $P$-value, with

381 larger circles indicating a more statistically significant differentially expressed transcript.

382 Biological processes are plotted according to their functional similarity using the $\operatorname{Sim}_{\text {Rel }}$

383 measurement (Schlicker et al. 2006) and REVIGO (Supek et al. 2011). 


\section{REFERENCES}

385 Anders S, Huber W (2010) Differential expression analysis for sequence count data. Genome Biology, 11, R106.

387

Borges JC, Fischer H, Craievich AF, Ramos CHI (2005) Low resolution structural study of two human HSP40 chaperones in solution. DJA1 from subfamily A and DJB4 from subfamily B have different quaternary structures. Journal of Biological Chemistry, 280, 13671-13681.

Benedetti-Cecchi L, Trussell GC (2014) Rocky intertidal communities. In: Marine Community Ecology and Conservation (eds Bertness MD, Bruno JF, Silliman BR, and Stachowicz JJ), pp. 203-225. Sinauer Associates, Sunderland.

Chang SC, Wooden SK, Nakaki T et al. (1987) Rat gene encoding the 78-kDa glucose-regulated protein GRP78: its regulatory sequences and the effect of protein glycosylation on its expression. Proceedings of the National Academy of Sciences, USA, 84, 680-684.

Chu ND, Kaluziak ST, Trussell GC, Vollmer SV (2014) Phylogenomic analyses reveal latitudinal population structure and polymorphisms in heat stress genes in the North Atlantic snail Nucella lapillus. Molecular Ecology. 23, 1863-1873.

Cody MJ, Salkowski CA, Henricson BE et al. (1997) Effect of inflammatory and antiinflammatory stimuli on acyloxyacyl hydrolase gene expression and enzymatic activity in murine macrophages. Innate Immunity, 4, 371-379.

Collén J, Guisle-Marsollier I, Léger JJ, Boyen C (2007) Response of the transcriptome of the intertidal red seaweed Chondrus crispus to controlled and natural stresses. New Phytologist, 176, 45-55. 
405 Connor KM, Gracey AY (2011) Circadian cycles are the dominant transcriptional rhythm in the 406 intertidal mussel Mytilus californianus. Proceedings of the National Academy of Sciences, $407 \quad$ USA, 108, 16110-16115.

408 Craig DW, Pearson J V, Szelinger S et al. (2008) Identification of genetic variants using bar409 coded multiplexed sequencing. Nature Methods, 5, 887-893.

410 Creel S, Winnie JA, Christianson D (2009) Glucocorticoid stress hormones and the effect of 411 predation risk on elk reproduction. Proceedings of the National Academy of Sciences, USA, $412 \quad \mathbf{1 0 6}, 12388-12393$.

413 Dennis EA, Rhee SG, Billah MM, Hannun YA (1991) Role of phospholipase in generating lipid 414 second messengers in signal transduction. FASEB Journal, 5, 2068-2077.

415 Dong Y, Miller LP, Sanders JG, Somero GN (2008) Heat-shock protein 70 (Hsp70) expression in 416 four limpets of the genus Lottia: interspecific variation in constitutive and inducible synthesis correlates with in situ exposure to heat stress. Biological Bulletin, 215, 173-181.

418 Elran R, Raam M, Kraus R et al. (2014) Early and late response of Nematostella vectensis 419 transcriptome to heavy metals, $23,4722-4736$.

420 Etter RJ (1988) Physiological stress and color polymorphism in the intertidal snail Nucella $421 \quad$ lapillus. Evolution, 42, 660-680.

422 Fan J, Akabane H, Zheng X et al. (2007) Male germ cell-specific expression of a novel Patched423 domain containing gene Ptchd3. Biochemical and Biophysical Research Communications, $424 \quad 363,757-761$.

425 Feder ME, Hofmann GE (1999) Heat-shock proteins, molecular chaperones, and the stress 
response: evolutionary and ecological physiology. Annual Review of Physiology, 61, 243282.

428 Fraser BA, Weadick CJ, Janowitz I, Rodd FH, Hughes KA (2011) Sequencing and characterization of the guppy (Poecilia reticulata) transcriptome. BMC Genomics, 12, 202.

Gardeström J, Elfwing T, Löf M et al. (2007) The effect of thermal stress on protein composition in dogwhelks (Nucella lapillus) under normoxic and hyperoxic conditions. Comparative Biochemistry and Physiology: Part A, Molecular and Integrative Physiology, 148, 869-875.

Grabherr MG, Haas BJ, Yassour M et al. (2011) Full-length transcriptome assembly from RNASeq data without a reference genome. Nature Biotechnology, 29, 644-652. fluctuating intertidal environment. Current Biology, 18, 1501-1507. human acyloxyacyl hydrolase, a leukocyte enzyme that deacylates bacterial lipopolysaccharides. Biochemistry, 30, 8415-8423. RNAs produced by alternative splicing and differential polyadenylation. Biochemistry, 27,

Helmuth BS, Hofmann GE (2001) Microhabitats, thermal heterogeneity, and patterns of physiological stress in the rocky intertidal zone. Biological Bulletin, 201, 374-384.

445 Helmuth BS, Mieszkowska N, Moore P, Hawkins SJ (2006) Living on the edge of two changing 446 worlds: forecasting the responses of rocky intertidal ecosystems to climate change. Annual 
Review of Ecology, Evolution, and Systematics, 37, 373-404.

448 Ishizaka K (1984) Regulation of IgE synthesis. Annual Review of Immunology, 2, 159-182.

449 Jones KMM, Boulding EG (1999) State-dependent habitat selection by an intertidal snail: the 450 costs of selecting a physically stressful microhabitat. Journal of Experimental Marine $451 \quad$ Biology and Ecology, 242, 149-177.

452 Kagawa N, Mugiya Y (2002) Brain HSP70 mRNA expression is linked with plasma cortisol 453 levels in goldfish (Carassius auratus) exposed to a potential predator. Zoological Science, $454 \quad 19,735-740$.

455 Kalia SK, Lee S, Smith PD et al. (2004) BAG5 inhibits parkin and enhances dopaminergic 456 neuron degeneration. Neuron, 44, 931-945.

457 Kishida O, Trussell GC, Nishimura K (2007) Geographic variation in a predator-induced defense $458 \quad$ and its genetic basis. Ecology, 88, 1948-1954.

459 Kregel KC (2002) Heat shock proteins: modifying factors in physiological stress responses and 460 acquired thermotolerance. Journal of Applied Physiology, 92, 2177-2186.

461 Lang RP, Bayne CJ, Camara MD et al. (2009) Transcriptome profiling of selectively bred Pacific 462 oyster Crassostrea gigas families that differ in tolerance of heat shock. Marine $463 \quad$ Biotechnology, 11, 650-668.

464 Langmead B, Trapnell C, Pop M, Salzberg SL (2009) Ultrafast and memory-efficient alignment 465 of short DNA sequences to the human genome. Genome Biology, 10, R25.

466 Liu F, Wang W, Sun X, Liang Z, Wang F (2013) RNA-Seq revealed complex response to heat 467 stress on transcriptomic level in Saccharina japonica (Laminariales, Phaeophyta). Journal of 
Applied Phycology, 26, 1585-1596.

469 Liu Y, Zhou J, White KP (2013) RNA-seq differential expression studies: more sequence or more replication? Bioinformatics, 30, 301-304.

471

473

474

475

476

477

478

480

482

484

485

486

487

488

Lockwood BL, Sanders JG, Somero GN (2010) Transcriptomic responses to heat stress in invasive and native blue mussels (genus Mytilus): molecular correlates of invasive success. Journal of Experimental Biology, 213, 3548-3558.

Long JD, Hay ME (2012) The impact of trait-mediated indirect interactions in marine communities. In: Trait-Mediated Indirect Interactions: Ecological and Evolutionary Perspectives (eds Ohgushi T, Schmitz O, and Holt RD), pp. 47-68. Cambridge University Press, Cambridge.

Miller LP, Matassa CM, Trussell GC (2014) Climate change enhances the negative effects of predation risk on an intermediate consumer. Global Change Biology.

Mardis ER (2008) Next-generation DNA sequencing methods. Annual Review of Genomics and Human Genetics, 9, 387-402.

Matassa CM, Trussell GC (2011) Landscape of fear influences the relative importance of consumptive and nonconsumptive predator effects. Ecology, 92, 2258-2266.

Miyakawa H, Imai M, Sugimoto N et al. (2010) Gene up-regulation in response to predator kairomones in the water flea, Daphnia pulex. BMC Developmental Biology, 10, 45.

Mizrokhi LJ, Mazo AM (1990) Evidence for horizontal transmission of the mobile element jockey between distant Drosophila species. Proceedings of the National Academy of Sciences, USA, 87, 9216-9220. 
Morabito MA, Moczydlowski E (1994) Molecular cloning of bullfrog saxiphilin: a unique relative of the transferrin family that binds saxitoxin. Proceedings of the National Academy of Sciences, USA, 91, 2478-2482.

Mori T, Kawachi H, Imai C et al. (2009) Identification of a novel uromodulin-like gene related to predator-induced bulgy morph in anuran tadpoles by functional microarray analysis. PLoS One, 4, e5936.

Munford RS, Hunter JP (1992) Acyloxyacyl hydrolase, a leukocyte enzyme that deacylates bacterial lipopolysaccharides, has phospholipase, lysophospholipase, diacylglycerollipase, and acyltransferase activities in vitro. Journal of Biological Chemistry, 267, 10116-10121.

Nauseef WM, Cogley M, McCormick S (1996) Effect of the R569W missense mutation on the biosynthesis of myeloperoxidase. Journal of Biological Chemistry, 271, 9546-9549.

Negri A, Llewellyn L (1998) Comparative analyses by HPLC and the sodium channel and saxiphilin 3H-saxitoxin receptor assays for paralytic shellfish toxins in crustaceans and molluscs from tropical North West Australia. Toxicon, 36, 283-298.

Ng SW, Wiedemann M, Kontermann R, Petersen G (1992) Molecular characterization of a putative peroxidase gene of Drosophila melanogaster. Biochimica et biophysica acta, 1171, $224-228$.

Paine RT (1966) Food web complexity and species diversity. American Naturalist, 100, 65-75.

Palmer AR (1990) Effect of crab effluent and scent of damaged conspecifics on feeding, growth, and shell morphology of the Atlantic dogwhelk Nucella lapillus ( L .). Hydrobologia, 193, $155-182$. 
510 Pascoal S, Carvalho G, Vasieva O et al. (2013) Transcriptomics and in vivo tests reveal novel 511 mechanisms underlying endocrine disruption in an ecological sentinel, Nucella lapillus. $512 \quad$ Molecular Ecology, 22, 1589-1608.

513 Pascoe PL, Jha AN, Dixon DR (2004) Variation of karyotype composition and genome size in 514 some muricid gastropods from the Northern Hemisphere. Journal of Molluscan Studies, 70, $515 \quad 389-398$.

516 Pauwels K, Stoks R, de Meester L (2005) Coping with predator stress: interclonal differences in 517 induction of heat-shock proteins in the water flea Daphnia magna. Journal of Evolutionary 518 Biology, 18, 867-872.

519 Pearson GA, Hoarau G, Lago-Leston A et al. (2010) An expressed sequence tag analysis of the 520 intertidal brown seaweeds Fucus serratus (L.) and F. vesiculosus (L.) (Heterokontophyta, 521 Phaeophyceae) in response to abiotic stressors. Marine Biotechnology, 12, 195-213.

522 Pijanowska J, Kloc M (2004) Daphnia response to predation threat involves heat-shock proteins 523 and the actin and tubulin cytoskeleton. Genesis, 38, 81-86.

524 Pincebourde S, Sanford E, Helmuth BS (2008) Body temperature during low tide alters the 525 feeding performance of a top intertidal predator. Limnology and Oceanography, 53, 1562$526 \quad 1573$.

527 Place SP, Menge BA, Hofmann GE (2012) Transcriptome profiles link environmental variation 528 and physiological response of Mytilus californianus between Pacific tides. Functional $529 \quad$ Ecology, 26, 144-155.

530 Roberts A, Pachter L (2013) Streaming fragment assignment for real-time analysis of sequencing 
experiments. Nature Methods, 10, 71-73.

532 Rothe M, Pan MG, Henzel WJ, Ayres TM, Goeddel DV (1995) The TNFR2-TRAF signaling

533 complex contains two novel proteins related to baculoviral inhibitor of apoptosis proteins.

$534 \quad$ Cell, 83, 1243-1252.

535 Rovero F, Hughes R, Chelazzi G (1999) Cardiac and behavioural responses of mussels to risk of 536 predation by dogwhelks. Animal Behaviour, 58, 707-714.

537 Sanogo YO, Hankison S, Band M, Obregon A, Bell AM (2011) Brain transcriptomic response of 538 threespine sticklebacks to cues of a predator. Brain, Behavior and Evolution, 77, 270-285.

539 Schlicker A, Domingues FS, Rahnenführer J, Lengauer T (2006) A new measure for functional 540 similarity of gene products based on Gene Ontology. BMC Bioinformatics, 7, 302

541 Schwarzenberger A, Courts C, von Elert E (2009) Target gene approaches: gene expression in 542 Daphnia magna exposed to predator-borne kairomones or to microcystin-producing and 543 microcystin-free Microcystis aeruginosa. BMC Genomics, 10, 527.

544 Sheriff MJ, Krebs CJ, Boonstra R (2009) The sensitive hare: sublethal effects of predator stress 545 on reproduction in snowshoe hares. Journal of Animal Ecology, 78, 1249-1258.

546 Slos S, Stoks R (2008) Predation risk induces stress proteins and reduces antioxidant defense. $547 \quad$ Functional Ecology, 22, 637-642.

548 Somero GN (2002) Thermal physiology and vertical zonation of intertidal animals: optima, 549 limits, and costs of living. Integrative and Comparative Biology, 42, 780-789.

550 Spanier KI, Leese F, Mayer C et al. (2010) Predator-induced defences in Daphnia pulex: 551 selection and evaluation of internal reference genes for gene expression studies with real- 
553 Stickle WB, Moore MN, Bayne BL (1985) Effects of temperature, salinity and aerial exposure on 554 predation and lysosomal stability of the dogwhelk Thais (Nucella) lapillus (L.). Journal of 555 Experimental Marine Biology and Ecology, 93, 235-258.

556 Supek F, Bošnjak M, Škunca N, Šmuc T (2011) REVIGO summarizes and visualizes long lists of 557 Gene Ontology terms. PLoS One, 6, e21800.

558 Tokunaga F, Muta T, Iwanaga S et al. (1993) Limulus hemocyte transglutaminase. cDNA 559 cloning, amino acid sequence, and tissue localization. Journal of Biological Chemistry, 268, $560 \quad 262-268$.

561 Trussell GC, Ewanchuk PJ, Bertness MD (2003) Trait-mediated effects in rocky intertidal food 562 chains: predator risk cues alter prey feeding rates. Ecology, 84, 629-640.

563 Trussell GC, Ewanchuk PJ, Matassa CM (2006a) Habitat effects on the relative importance of 564 trait- and density-mediated indirect interactions. Ecology Letters, 9, 1245-1252.

565 Trussell GC, Ewanchuk PJ, Matassa CM (2006b) The fear of being eaten reduces energy transfer 566 in a simple food chain. Ecology, 87, 2979-2984.

567 Trussell GC, Ewanchuk PJ, Matassa CM (2008) Resource identity modifies the influence of 568 predation risk on ecosystem function. Ecology, 89, 2798-2807.

569 Turner AM, Montgomery SL (2003) Spatial and temporal scales of predator avoidance:

570 experiments with fish and snails. Ecology, 84, 616-622.

571 Wagner BA, Buettner GR, Oberley LW, Darby CJ, Burns CP (2000) Myeloperoxidase is 572 involved in H2O2-induced apoptosis of HL-60 human leukemia cells. Journal of Biological 
574 Westram AM, Galindo J, Rosenblad MA et al. (2014) Do the same genes underlie parallel

575 phenotypic divergence in different Littorina saxatilis populations? Molecular Ecology, 23, $576 \quad 4603-4616$.

577 Yuki S, Inouye S, Ishimaru S, Saigo K (1986) Nucleotide sequence characterization of a 578 Drosophila retrotransposon, 412. European Journal of Biochemistry, 158, 403-410.

579 Zheng J, Shen W, He DZ et al. (2000) Prestin is the motor protein of cochlear outer hair cells. $580 \quad$ Nature, $\mathbf{4 0 5}, \mathbf{1 4 9 - 1 5 5 .}$ 


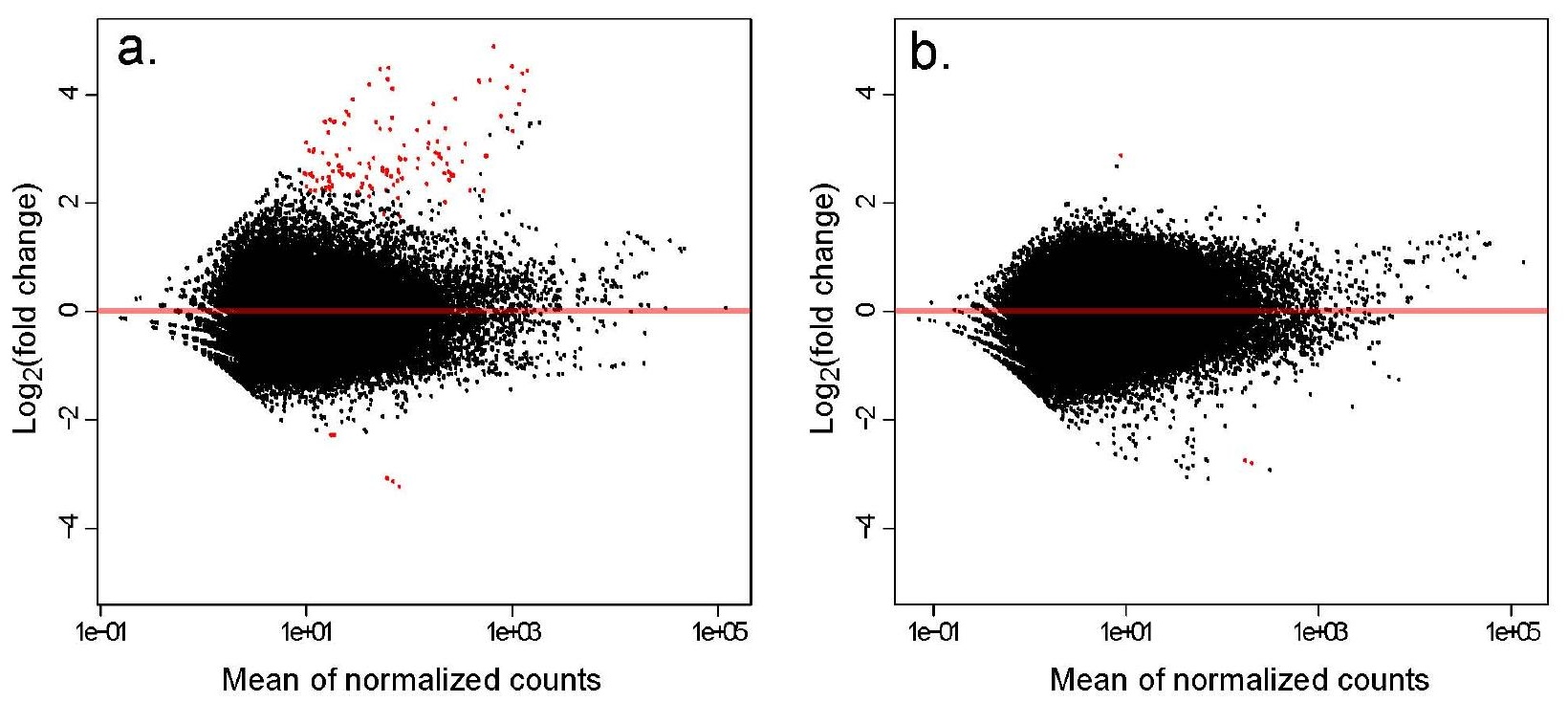




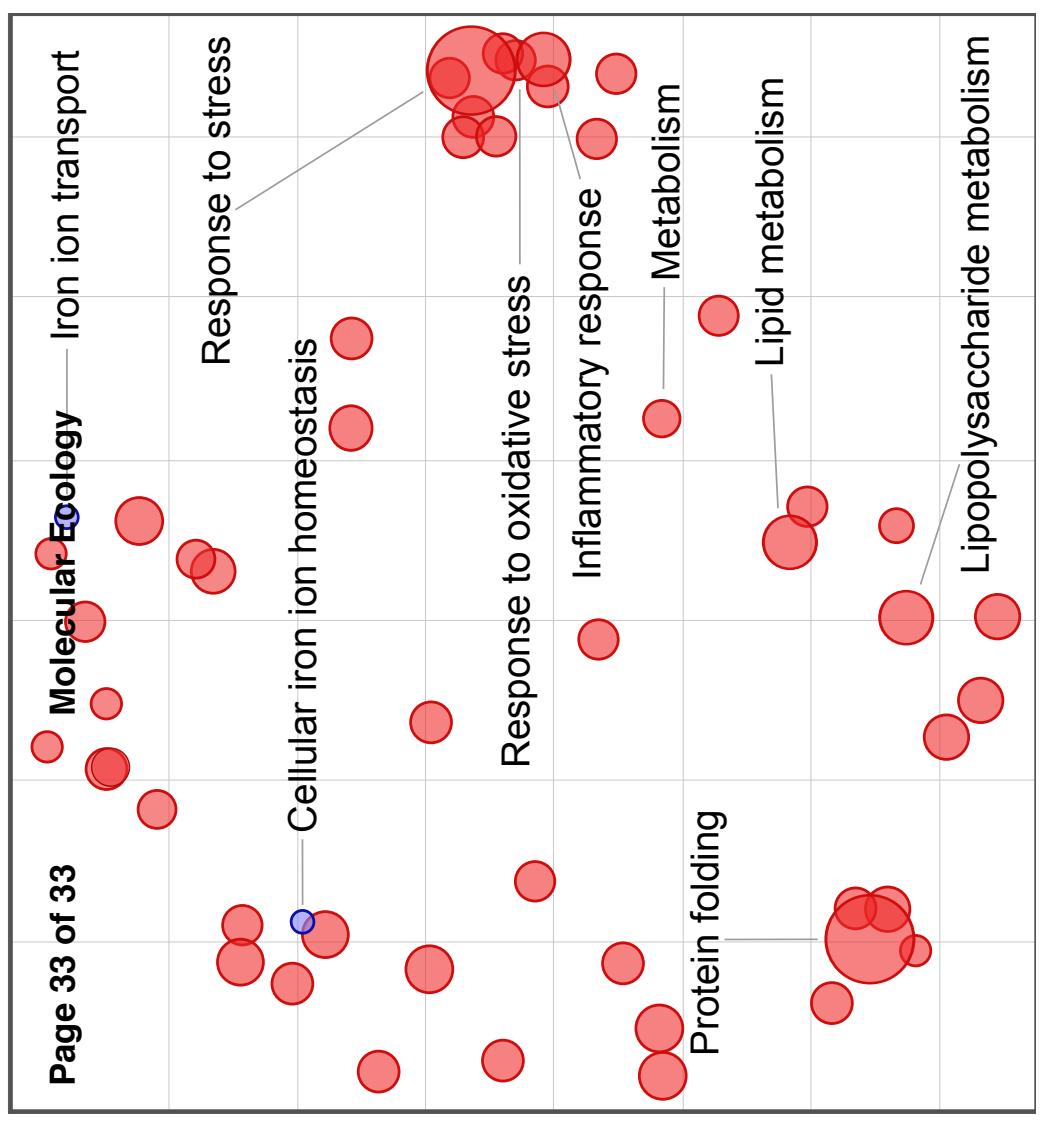


Supporting Information

Table S1. Illumina read representation of individual snails.

\begin{tabular}{|l|l|l|l|}
\hline Sample & Filtered Reads & $\begin{array}{l}\text { Mapping } \\
\text { Reads }\end{array}$ & Annotated, Mapping Reads \\
\hline AC_006 & $6,020,717$ & $3,432,767$ & 718,576 \\
\hline AC_008 & $7,037,731$ & $4,289,831$ & 893,364 \\
\hline AC_43 & $1,324,128$ & 702,278 & 210,358 \\
\hline AC_42 & $1,857,540$ & 883,589 & 273,892 \\
\hline $\begin{array}{l}\text { ANC_00 } \\
\text { 3 }\end{array}$ & $5,782,131$ & $3,568,060$ & 715,620 \\
\hline ANC_34 & $5,577,022$ & $2,594,866$ & 927,301 \\
\hline ANC_41 & $4,575,798$ & $2,293,349$ & 911,726 \\
\hline HNC_31 & $3,677,763$ & $1,891,007$ & 657,755 \\
\hline HNC_37 & $6,227,059$ & $3,002,492$ & 941,372 \\
\hline
\end{tabular}

Table S2. Nucella lapillus transciprtome assembly metrics.

\begin{tabular}{|l|l|l|}
\hline $\begin{array}{l}\text { Total base length of } \\
\text { assembly }\end{array}$ & Contigs & Annotated contigs \\
\hline $44,210,724$ & 90,674 & 20,922 \\
\hline
\end{tabular}

